певного вищого навчального закладу на ринку праці. У мережі Інтернет можна знайти велику кількість статей і публікацій, в тому числі і молодих вчених, проблеми працевлаштування та адаптації молоді. Однак, складно знайти інформацію про успішні корпоративні програми підтримки молоді.

Розвиток ефективних корпоративних систем управління організаційної культурою може стати міцною основою для трудової адаптації молодих фахівців в сучасних складних умовах трансформації глобальних i локальних ринків праці, а також істотно вплинути на зростання інноваційної складової економічного розвитку великих корпорацій, організацій, підприємств та бізнесу.

\section{ПЕРЕЛІК ВИКОРИСТАНИХ ДЖЕРЕЛ}

1. Про сприяння соціальному становленню та розвитку молоді України: Закон України Оф. сайт Державної служби статистики України [Електронний ресурс]. - Режим доступу: http://www.rada.gov.ua

2. Гриценко Н.В. Перспективы альтернативного железнодорожного

транспорта современным руководителем / Н.В. Гриценко // «Ученые записи»-Scientifics works, Азербайджанского Технического Университета. Баку:-2014. - №1.- С. 129132.

3. Гриценко Н.В. Теоретический поход к проблеме мотивации персоналом на железнодорожном транспорте / Н.В. Гриценко // Зб. наук. праць. Технік. прогрес і ефект. виробництва -Харків: ХТУ «ХПІ». 2016. - №27 (1199). - C. 38-43.

4. Гриценко Н.В. Діяльність менеджера в сфері управління людськими ресурсами / Н.В. Гриценко // Вісник економіки транспорту і промисловості. 2016. - №54. - С. 345 - 349.

5. Лисенко Л.І. Ринок праці. Техніка пошуку роботи : навч. посіб. для студ. вищ. навч. закл. / Л.І. Лисенко, Б.В. Максимов, В.К. Маригодов. - К.: Вид. дім «Професіонал», 2004. - 311 с.

6. Щотова Ю.М. Правове регулювання працевлаштування молоді в Україні / Ю.М. Щотова; Академія праці і соціальних відносин Федерації професійних спілок України. - К.: АПСВ, 2007. $-192 \mathrm{c}$.

УДК 658.14 (477)

\title{
ДОСЛІДЖЕННЯ МОДЕЛЕЙ СОЦІАЛЬНОЇ ВІДПОВІДАЛЬНОСТІ У БІЗНЕСОВОМУ СЕРЕДОВИЩІ ТА МОЖЛИВОСТЕЙ ЇХ ЗАСТОСУВАННЯ В УКРАЇНI
}

\author{
Панченко Н.Г., к.е.н., доцент (УкрДУЗТ)
}

\begin{abstract}
Визначено, щуо сочіальну відповідальність бізнесу можна визначити як добровільне зобов'язання бізнес-організащій проводити таку політику, приймати такі рімення, розвивати такі напрямки діяльності, які є бажаними з точки зору цілей та цінностей суспільства. Зроблено висновок, щуо особливість СВБ в Україні - це ігнорування українськими компаніями базового рівня сочіальної відповідальності $i$ іï реалізачія на другому і третьому рівнях. В той же час, розширення сфери СВБ за рамки базового рівня $i$, тим більше за межі корпорації, зустрічає протест з боку ії працівників. Бізнес-структури при обранні напрямків сочіальних інвестицій надають перевагу тим з
\end{abstract}

(C) Панченко Н.Г.

Вісник економіки транспорту і промисловості № 60, 2017 
них, які мають чітко виражений іміджевий характер та можуть викликати суспільний резонанс.

Ключові слова: соціальна відповідальність бізнесу, фінансово-економічна криза, цінності суспільства, корпорації, імідж, суспільство.

\title{
ИССЛЕДОВАНИЕ МОДЕЛЕЙ СОЦИАЛЬНОЙ ОТВЕТСТВЕННОСТИ В БИЗНЕС-СРЕДЕ И ВОЗМОЖНОСТИ ИХ ПРИМЕНЕНИЯ В УКРАИНЕ
}

\author{
Панченко Н.Г., к.э.н., доцент (УкрГУЖТ)
}

\begin{abstract}
Определено, что социальную ответственность бизнеса можно определить, как добровольное обязательство бизнес-организаций проводить такую политику, принимать такие решения, развивать такие направления деятельности, которые желательны с точки зрения целей и ценностей общества. Сделан вывод, что особенность СВБ в Украине - это игнорирование украинскими компаниями базового уровня социальной ответственности и ее реализачия на втором и третьем уровнях. $B$ то же время, расширение сферы СВБ за рамки базового уровня и, тем более за предель корпорации, встречает протест со стороны ее работников. Бизнес-структуры при выборе направлений сочиальных инвестиций предпочитают те из них, которые имеют четко выраженный имиджевый характер и могут вызвать общественный резонанс.
\end{abstract}

Ключевые слова: социальная ответственность бизнеса, финансовоэкономический кризис, ценности общества, корпорации, имидж, общество.

\section{RESEARCH OF SOCIAL RESPONSIBILITY MODELS IN THE BUSINESS ENVIRONMENT AND THEIR APPLICABILITY IN UKRAINE}

\section{Panchenko N.G., Ph.D. in Economics, associate Professor (UkrSURT)}

The urgency of social and ethical business is exacerbated by some circumstances: firstly, the financial and economic crisis, which has not yet ended, therefore its root causes have not been eliminated; and secondly, the growing recognition of the urgency of an environmental problem of a global nature; Thirdly, the transition of the world economy, the bulk of which is concentrated in industrialized countries, from the 5th to the 6th technical and economic terms. Although the final contours of the new model have not yet been determined, it is clear that it must be distinguished by a greater degree of social and environmental responsibility. That is, caring for competitiveness in the market should be combined with social responsibility to society. Social responsibility of a business can be defined as the voluntary commitment of business organizations to pursue such a policy, to make such decisions, to develop such activities that are desirable in terms of the goals and values of society. There are several CSR models in the world, each of which reproduces the socioeconomic structure of a country. The most famous are the American and European models of social partnership, which influence the formation of the system of CSR. The peculiarity of CSR in Ukraine is the ignorance by the Ukrainian companies of the basic level of social responsibility and its implementation at the second and third levels. At the same time, the expansion of the sphere of CSR beyond the base level and, especially beyond the limits of the corporation, meets the protest of its employees. 
Yes, they believe that the degree of their own social security is not so high that the company implements social programs that are not directly targeted at the staff. However, the business structure chooses social investment areas to give priority to those that have a clearly expressed image character and can cause a public response.

Key words: social responsibility of business, financial and economic crisis, values of society, corporations, image, society.

Постановка проблеми та її зв'язки 3 науковими чи практичними завданнями. У багатьох відношеннях поняття соціальної відповідальності бізнесу є мостом між макро- і мікрорівнем прийняття етичних рішень. Це пов'язано 3 тим, що, як правило, важливу роль у розвитку та підтримці соціальної відповідальності підприємницької діяльності відіграє держава. I навпаки: рішення фірми, що стосуються соціальних проблем, можуть у певних випадках впливати на державну політику. Більше того, в області соціальної відповідальності часто спостерігається свого роду «демонстраційний ефект».

До того ж актуальність ведення соціально-етичного бізнесу посилюють деякі обставини: по-перше, фінансовоекономічна криза, яка, ще не закінчилася, тому не усунені іiі корінні причини; подруге, зростання визнання нагальності екологічної проблеми, що носить глобальний характер; по-третє, перехід світової економіки, велика частина продукту якої зосереджена в промислово розвинених країнах, від 5-го до 6-го техніко-економічного укладу. Хоча остаточні контури нової моделі поки не визначилися, але вже ясно, що вона повинна відрізнятися більшим ступенем соціальної та екологічної відповідальності. Тобто турбота про конкурентоспроможність на ринку повинна поєднуватися із соціальною відповідальністю перед суспільством.

Аналіз останніх досліджень i публікацій. Проблематика соціальної відповідальності бізнесу на даний час $є$ доволі популярним науковим напрямком. Достатньо глибоко дана тематика розглядається у роботах Ю. Грудзевич [2],
О. Ворожбит, Н. Титової [1], О. Мочерної [9], В. Кисельової [7], Ф. Хміль [13], М. Стародубської [12], М. Ліборакіної [8], А. Зінченко, М. Сапкикіної [10] та ін. Окремі аспекти сутності соціальної відповідальності бізнесу й особливостей іiі формування розглянуто у працях В. Диканя, Ю. Боровика, О. Полякової, Ю. Уткіної, В. Компанієць, В. Зубенко, О. Маковоз, І. Токмакової, О. Шраменко [3-5].

Виділення невирішених частин загальної проблеми. Не дивлячись на велику кількість праць, присвячених дослідженню соціальної відповідальності бізнесу окрему увагу, на нашу думку, слід приділити вивченню моделей формування соціальної відповідальності бізнесу та проблематиці їх застосування в реаліях української економіко-політичної ситуації.

Формування цілей статті (постановка завдання). Саме тому метою статті $є$ дослідження моделей соціальної відповідальності у бізнесовому середовищі та можливостей їх застосування в Україні.

Виклад основного матеріалу дослідження. Єдиного визначення соціальної відповідальності бізнесу (СВБ) немає i, певно, не може бути, оскільки йдеться про системний підхід до комплексної проблеми.

Якщо узагальнити визначення СВБ більше 50 міжнародних організацій, серед яких Світовий Банк, ООН, Business for Social Responsibility, Caux Round Table, Corporate Citizenship International, European Academy for Business in Society, European Association of Communication Agencies (EACA), International Business Leaders Forum ( IBLF), Market Opinion Research Institute (MORI), Social Accountability International, World Business Council for 
Sustainable Development, соціальна відповідальність як підхід до бізнесу має наступний набір характеристик:

- СВБ це добровільний вибір компанії, в умовах зростаючої конкуренцією i зниження довіри до бізнесу;

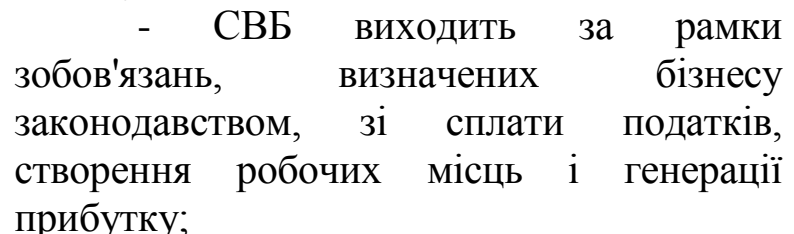

- СВБ включає всіх членів місцевого співтовариства: бізнес, ЗМI, владу, неприбуткові організації, населення, інвесторів тощо;

- СВБ це не спосіб вирішити проблеми суспільства за рахунок бізнесу, а спосіб брати участь у розвитку того середовища, в якій бізнес працює;

- СВБ це підхід до сталого розвитку 3 прямим (як правило, довгостроковим) впливом на фінансові показники компанії [12].

Узагальнюючи наведене вище, соціальну відповідальність бізнесу можна визначити як добровільне зобов'язання бізнес-організацій проводити таку політику, приймати такі рішення, розвивати такі напрямки діяльності, які $\epsilon$ бажаними з точки зору цілей та цінностей суспільства.

Дослідники виділяють чотири основні позиції до визначення відповідальності:

- юридична відповідальність, тобто будь-які дії в межах юридичної зайнятості вважаються соціально відповідальними;

- професійна відповідальність, яка диктується нормами взаємодії професіонала i наймача; будь-які дії в межах вказаних норм вважаються соціально відповідальними;

- економічна відповідальність, якщо діяльність веде до успіху, досягненню цілей компанії в економіці; якщо цього немає, то соціальна відповідальність не може бути реалізована, тому від неї слід відмовитися;
- морально-етична відповідальність, це соціальна відповідальність як перед людьми, так і перед усіма, хто опиняється в колі впливу їі діяльності [7].

Всі чотири позиції повинні бути об'єднані в один спільний соціальноорієнтований курс діяльності підприємців.

Існує дві точки зору щодо соціальної ролі підприємця.

Традиційна, що полягає в тому, що головна ціль його діяльності полягає в максимізації прибутку, зрозуміло, при дотриманні законодавства, що встановлює правила гри на ринку, ведення чесної конкурентної боротьби і порядних взаємин 3 партнерами і кінцевими споживачами.

Сучасна позиція 3 цього питання полягає в тім, що будь-яка справа здійснюється у складному соціальному оточенні, яке прагне отримати від підприємця кошти через оподаткування на освіту, охорону здоров'я, управління, охорону суспільного порядку, оборону i т.д. Успіх справи буде прочнішим та довготривалішим, якщо підприємець буде відчувати соціальні запити і самостійно в них брати участь, якщо він призведе у розумну рівновагу свої економічні інтереси та інтереси суспільства (рис. 1).

В науковій літературі виділяють чотири групи поглядів на питання соціальної відповідальності підприємств.

Перша група полягає у тому, що підприємці, керуючись власним сумлінням, здійснюють добровільну благодійну діяльність у формі підтримки соціально незахищених верств населення та меценатства.

Друга група поглядів визначає соціальну відповідальність підприємництва через забезпечення власної ефективної діяльності, зайнятості населення та недопущенні порушень законів держави.

Відповідно до третьої групи поглядів, суспільство очікує активних дій власників капіталів у таких сферах, як захист навколишнього середовища, охорона здоров'я, громадянські права, захист споживачів. 
Забезпечення потреб суспільства у потрібній кількості, різноманітності та якості товарів (робіт, послуг)
Участь у соціальних програмах, які ініціюються владою та суспільними організаціями - благодійність, зниження безробіття, охорона довкілля, боротьба з бідністю
Впровадження досягнень науковотехнічного прогресу, матеріало- та енергозберігаючих технологій, забезпечення екологічності віробництва

Соціальна відповідальність підприємництва

Рис. 1. Основні напрями соціальної поведінки підприємия [7]

Прихильники четвертої групи поглядів вважають, що держава $є$ основним виразником інтересів суспільства i відповідними правовими актами регламентує відповідальність підприємництва перед ним [13].

У світі існує декілька моделей СВБ, кожна 3 яких відтворює суспільноекономічний уклад тієї чи іншої країни. Найбільш відомими $\epsilon$ американська та європейська моделі соціального партнерства, що впливають на формування системи СВБ.

Американська модель соціального партнерства характерна для США, Канади, Японії, країн Латинської Америки, а також англомовних країн Африки. У $\dddot{1}$ основі лежить регулювання державою соціальнотрудових відносин на рівні підприємства і у значно меншій мірі - на рівні галузі та регіону шляхом прийняття законодавчих та нормативних актів [9]. В американській моделі переважає ухил на філантропію, тобто, компанія ділиться частиною прибутку, інвестуючи його в суспільнокорисні ініціативи. I чим менше можливість простежити зв'язок між соціально-відповідальними «вкладеннями» компанії і досягненням іiї бізнес-цілей, тим краще.

У сучасних економічних умовах американська модель соціально відповідальної поведінки компаній використовується найбільш широко. Основні повідомлення, які промислова компанія несе цільовим групам: екологічність роботи, стабільність і надійність, людяність [11].

Щодо європейської моделі, соціально-відповідальна діяльність компанії пов'язана 3 досягненням іiі бізнесцілей i $\epsilon$ частиною стратегії створення додаткової вартості компанії. Європейська модель передбачає економічне обгрунтування соціальних ініціатив та їх інтеграцію в стратегію розвитку компанії. Основні повідомлення, які промислова компанія несе цільовим групам: прозорість, керованість і стабільність, турбота, надійність [9].

Основні розбіжності у відношенні до концепції соціальної відповідальності підприємств у США та країнах Європи визначаються на рівні відносин підприємство - держава. Так, якщо діяльність американських корпорацій загалом визначається його власниками та керівниками, то європейські компанії зазнають значного впливу 3 боку державних органів влади та професійних об'єднань, які жорстко визначають мінімальні вимоги до їх діяльності $[1 ; 8]$. 
3 точки зору інвестора, європейська модель є більш привабливою при оцінці соціально-відповідальної поведінки компанії, оскільки може бути зведена до відносно вимірюваних результатів. Як і американська модель, європейська модель сприяє поліпшенню іміджу та репутації компанії в очах місцевої громади та сприяє встановленню довіри до комунікацій компанії.

При певних перевагах, європейська модель має ряд особливостей, які слід враховувати перед іiі впровадженням в промисловій компанії. Перш за все, необхідно оцінити готовність компанії переглянути свою діяльність для приведення іiі у відповідність зі стратегією соціально відповідальної поведінки i можливість розробки механізмів обчислення економічного ефекту. До того ж, європейська модель має меншу ступінь гнучкості у виборі об'єктів вкладень, оскільки в рамках цієї моделі компанія вибирає пріоритетні для себе соціальні сфери і концентрується тільки на них.

Британська модель СВБ поєднує у собі елементи американської та континентальної моделей. Загальною рисою цієї моделі $є$, перш за все, активна підтримка бізнесу з боку держави та добре розроблена система заходів соціального забезпечення та охорони здоров'я. Участь влади у розвитку СВБ виявляється у налагоджені партнерства із власниками підприємств у секторі освіти, які беруть участь у фінансуванні проектів, наданні податкових пільг, просуванні ініціатив щодо відповідності національних стандартів до міжнародних [14].

За джерелами регулювання практикою український варіант СВБ $\epsilon$ сумішшю британської моделі та континентальної схеми. В Україні СВБ продовжує орієнтуватися на ближче коло стейкхолдерів: державу, власників та персонал. Найчастіше під терміном «стейкхолдери» мають на увазі групи, організації або індивідууми, на яких впливає компанія і від яких вона залежить.
Більш широке коло зацікавлених сторін це місцева громада, постачальники та інші, поки що так і не є системною ознакою. Сьогодні СВБ в Україні - це добровільний внесок приватного сектора у громадський розвиток через благодійність та механізм соціальних інвестицій [14].

Соціальна відповідальність бізнесу має багаторівневий характер.

Перший рівень, базовий, $\epsilon$ стартовою умовою СВБ. Він включає виконання компанією своїх прямих зобов'язань перед суспільством та державою: регулярна та в повному обсязі виплата заробітної платні; дотримання норм законодавства про працю; своєчасна i в повному обсязі сплата всіх належних податків; забезпечення встановлених стандартів якості продукції. Багато ліберально налаштованих аналітиків вважають, що цим рівнем СВБ вичерпується, оскільки «справа бізнесу бізнес».

Другий рівень передбачає розвиток відносин всередині підприємства i безпосередне врахування інтересів працівників. До вище перелічених зобов'язань працівникам гарантується певний набір пільг і послуг - «соціальний пакет». Завдяки високому рівню соціального захисту, компанії вдається втримувати працівників, виплачуючи їм при цьому нижчу заробітну платню. Підтримуються також системи освіти та підготовки кадрів, які розглядаються як інвестиції в персонал [2].

Третій рівень соціальної відповідальності бізнесу охоплює соціальні програми і напрями діяльності, сфера дії яких виходить за межі компанії.

Особливість СВБ в Україні ігнорування українськими компаніями базового рівня соціальної відповідальності i iii реалізація на другому і третьому рівнях. В той же час, розширення сфери СВБ за рамки базового рівня i, тим більше за межі корпорації, зустрічає протест 3 боку іiі працівників. Так, вони вважають, що ступінь їх власної соціальної захищеності 
поки не настільки високий, щоб компанія реалізовувала соціальні програми, безпосередньо не орієнтовані на персонал. Однак бізнес структури при обранні напрямків соціальних інвестицій надають перевагу тим 3 них, які мають чітко виражений іміджевий характер та можуть викликати суспільний резонанс.

Третій рівень СВБ свідчить також про прагнення бізнес спільноти співробітничати 3 владою і впливати на рішення, які вона приймає. Пріоритетними завданнями в цьому зв'язку $\epsilon$ : участь підприємців та роботодавців у реалізації соціальних програм; взаємодія 3 місцевою владою i профспілками; лобіювання інтересів регіонального бізнесу; проведення політичної реформи в Україні; створення власної фракції в органах місцевого самоврядування. Таким чином, український бізнес демонструє готовність вирішувати разом із владою на державному i місцевому рівнях певну частину суспільно значущих завдань [11].

Згідно 3 Концепцією соціальної відповідальності бізнесу в Україні СВБ діє на трьох основних рівнях.

1 Дотримання законних зобов'язань перед державою і суспільством (сплата податків, охорона здоров'я і безпека праці, права працівників, права споживачів, екологічні норми) та галузевих стандартів.

2 Мінімізація або усунення негативного впливу бізнесу на суспільство та управління ризиками (наприклад, порушення прав людини або забруднення навколишнього середовища).

3 Посилення позитивного впливу бізнесу на суспільство і створення цінностей через інновації, інвестиції та партнерство, що спрямовані на соціальний та екологічний добробут (наприклад, створення робочих місць, соціальний та економічний розвиток, вирішення конфліктів) [10].

Передумовами становлення i розвитку СВБ в Україні $€$ наступні процеси, які характерні також i для пострадянських країн:
- суттєві зміни в структурі власників українських підприємств, що викликані трансформаційними процесами української економіки, економічною нестабільністю останніх років та перманентними політичними змінами. Чітко простежується тенденція до поступової концентрації власності, однак відсутні стійкі тенденції розвитку фондового ринку та зростання долі інституціональних інвесторів (пенсійні, інвестиційні фонди, страхові компанії, банки);

- відсутність реальних механізмів участі трудового колективу в управлінні підприємством після проведення приватизації власності;

- поєднання функцій топменеджменту та власників, які переслідують у першу чергу власні матеріальні інтереси;

- готовність підприємців до узгодження інтересів 3 представниками владних інститутів під впливом ряду причин;

- велика кількість соціальних, економічних та екологічних проблем, що певним чином підштовхує бізнес до більш активної участі в їх вирішенні і часто призводить практично до залучення бізнесу до виконання частини державних функцій;

- необхідність позиціонування України у міжнародному середовищі; - географічна належність до регіону зі стійкими традиціями у сфері СВБ - СС. Це створює підгрунтя для формування соціальної відповідальності бізнесу як певної стратегії розвитку, діяльності, усвідомлення відповідальності за сприяння та досягнення сталого розвитку компанії, громади, держави в цілому. Проте існує ряд причин недостатнього розвитку соціального підприємництва в Україні:

- загальний низький рівень підприємництва в країні, не лише соціального, нерівномірний розвиток бізнесу;

- зарегульованість сфер, в яких 
соціальне підприємництво може мати найбільший вплив - охорона здоров'я, соціальний захист тощо;

- низький рівень усвідомлення суспільством ролі бізнесу;

- родинні механізми (в Україні родина часто виконує функції соціального підприємництва);

- відсутність стимулювання 3 боку грантодавців - часто неурядовим організаціям простіше написати ще одну заявку на ще один проект замість того, щоб робити соціальний бізнес у своїй сфері;

- відсутність інформації про соціальне підприємництво в Україні;

- низький рівень корпоративної культури підприємств;

- правовий нігілізм і деформація правової свідомості;

- термінологічна (нормативна) невизначеність;

- закритість українських компаній для широкої громадськості;

- невиконання значною частиною підприємств законодавчо закріплених соціальних нормативів;

- неоднаковий ступінь використання різних форм соціальної відповідальності; недостатне усвідомлення підприємствами своєї ролі у рішенні соціальних та екологічних проблем суспільства.

\section{Результати}

досліджень визначають соціологічних перешкодами становлення та розвитку соціальної відповідальності бізнесу наступні: недосконалість законодавчої й нормативно-правової бази, що регулює можливості участі бізнесу в соціальних програмах та закладів освіти у формуванні соціально відповідальних фахівців; відсутність сформованої і дієвої незалежної громадянської експертизи та оцінки результатів соціальних програм, стандартів i якості підготовки бізнес-фахівців; відсутність системи заохочення (морального та економічного) відповідальних суспільних суб' єктів [6].

Крім того, чинна нормативно- правова база України щодо стимулювання зазначених суб'єктів має низку недоліків, серед яких слід зазначити:

- відсутність комплексності в підході до стимулювання;

- слабкий розвиток конкурсних засад у наданні пільг;

- низька технологічна розробленість процедур розгляду та прийняття рішень про стимулювання комерційних установ до участі у соціальних проектах;

- незахищеність бюджетних статей, пов'язаних 3 наданням пільг та інших видів стимулювання;

- вирішення питань про надання пільг покладені, як правило, на фінансові органи та інші незацікавлені інстанції;

- стимулюючі заходи в більшості випадків лише декларуються, але не $\epsilon$ обов’язковими тощо

Висновки даного дослідження i перспективи подальших робіт у цьому напрямку. В Україні ще не сформувалася національна модель соціальної відповідальності бізнесу. Огляд національних особливостей соціалізації бізнесу в Україні дає можливість зробити такі висновки:

- соціальна відповідальність бізнесу виникає як об'єктивна потреба не лише суспільства, а й самих підприємств, які прагнуть знайти своє місце в конкурентному середовищі, свого споживача, зацікавити до співпраці національних і зарубіжних партнерів, висококваліфікованих спеціалістів;

$$
\text { практики соціальної }
$$

відповідальності бізнесу не приживаються, якщо вони нав'язані міжнародними стандартами, законодавством чи будьякими суспільними структурами. Їх ефективність тим вища, чим конкретніша спрямованість і більш наглядний соціальний результат;

- потреба суспільства у тих чи інших формах соціальної відповідальності бізнесу складається під впливом національного менталітету, сучасного етапу розвитку процесів соціалізації та тих 
конкретних проблем, які неможливо розв'язати без вкладу бізнесових структур.

Найбільш ефективними заходами, які б поширювали принципи соціальної відповідальності бізнесу в українському суспільстві та стимулювали комерційні організації до вирішення соціальних проблем $\epsilon$ наступні:

$$
\text { створення }
$$

сприятливих

організаційно-правових умов для діяльності суб'єктів господарювання, що беруть участь у вирішенні соціальних проблем;

- надання пільг по податках, зборах, орендній платі та інших платежах підприємствам i організаціям, які займаються шефською, спонсорською, благодійною діяльністю;

- цільова фінансова підтримка недержавних суб'єктів соціальної політики за рахунок бюджетних коштів;

- застосування економічних та інших санкцій до тих, хто діє на шкоду соціальним інтересам територіальної громади;

- налагодження співпраці 3 податковими органами та проведення консультаційної і ознайомчої роботи тощо;

- акумулювання наявної інформації у сфері соціального підприємництва та адаптація закордонного досвіду соціального підприємництва.

\section{ПЕРЕЛІК ВИКОРИСТАНИХ ДЖЕРЕЛ}

1. Ворожбит,

O.Ю.

Предпринимательская среда как фактор взаимодействия предпринимательских структур [Текст] / О.Ю.Ворожбит, Н.Ю. Титова // Вестник Пермского университета. 2014. - Вып. 1(20). - С. 134139.

2. Грудзевич, Ю.І. Сутність механізму реалізації підприємницької діяльності та його складових [Текст] / Ю.І. Грудзевич // Наукові записки Національного університету «Острозька академія». Серія «Економіка». - 2014. Вип. 25. - С. 9-14.
3. Дикань, В.Л. Стратегічне управління [Текст]: навч. посіб./ В.Л. Дикань, В.О. Зубенко, О.В. Маковоз, I.В. Токмакова, О.В. Шраменко - К.: «Центр учбової літератури», 2013. - 272 с.

4. Дикань, В.Л. Етичні основи бізнесу [Текст]: підручник / В.Л. Дикань, В.В. Компанієць, О.М. Полякова. - Харків: УкрДАЗТ, 2012. - 316 с.

5. Дикань, В.Л. Забезпечення конкурентоспроможності підприємств [Текст]: підручник / В.Л. Дикань, Ю.Т. Боровик, О.М. Полякова, Ю.М. Уткіна. Харків: УкрДАЗТ, 2012. - 415 с.

6. Зінченко, А.Г. Корпоративна соціальна відповідальність 2005-2010: стан та перспективи розвитку [Текст] / А.Г. Зінченко, М.А. Сапкикіна - К.: Видавництво «Фарбований лист», 2010. $56 \mathrm{c}$.

7. Киселева, В.А. Социальная ответственность, культура и этика предпринимательства [Электронный ресурс] / В. А. Киселева // Вестник ЮУрГУ. Серия «Экономика и менеджмент». - Режим доступа: http://cyberleninka.ru/article/n/sotsialnayaotvetstvennost-kultura-i-etika-

predprinimatelstva

8. Либоракина, М.И. Социально ответственный бизнес: глобальные тенденции и опыт стран СНГ [Текст] / М. И. Либоракина. - М.: Фонд «Институт экономики города», 2001. - 72 с.

9. Мочерна, О.С. Світовий досвід КСВ i шляхи його ефективного впровадження в Україні [Електронний ресурс] / О.С. Мочерна. - Режим доступу: http:// www.rusnauka.com/18 NPM 2008/ Economics/ 34396.dok.htm

10. Національна концепція розвитку соціальної відповідальності бізнесу (СВБ) в Україні [Електронний ресурс]. - Режим доступу: $\quad$ www.pfi.org.ua/index.php? ption=com_docman\&task $=$ doc

11. Прогнімак, О.Д. Формування соціальної бізнесу: взаємодія $з$ місцевими спільнотами та владою [Електронний ресурс] / О.Д. Прогнімак, О.В. Іщенко, 
О.Ю. Касперович. - Режим доступу: http://www.nbuv.gov.ua/portal/soc_gum/Usoc /2006_5/94-105.pdf

12. Стародубская, М. Стратегия, милосердие, мода или PR? [Електронний peсурс] / М. Стародубська. - Режим доступу:

http://mm.com.ua/russian/articles/page/113

13. Хміль, Ф.I. Соціальна відповідальність підприємництва в Україні
[Текст] / Ф.І. Хміль // Економічний вісник Національного технічного університету України «Київський політехнічний інститут». - 2004. - №1. - С. 24-30.

14. Шляхи стимулювання соціальної відповідальності вітчизняного бізнесу [Електронний ресурс]. - Режим доступу http://www.lir.lg.ua/shlahi.doc

\title{
УДК 65.011:656.2
}

\section{СОЦІАЛЬНА ВІДПОВІДАЛЬНІСТЬ МАЛОГО БІЗНЕСУ ЯК ЙОГО КОНКУРЕНТНА ПЕРЕВАГА}

\author{
Полякова О.М., к.е.н., доцент, \\ Хорошаєва Є.В., махістр (УкрДУЗТ)
}

У статті розглянуто підходи до соиіальної відповідальності малого бізнесу, виявлено основні конкурентні переваги та проаналізовано риси моделей соиіальної відповідальності фірм. Встановлено, що соиіально відповідальна діяльність малих підприємств сприяє поліпшенню іміджу $i$ репутації брендів, підвищенню рівня продажів і зростанню лояльності споживачів, скороченню тиску з боку перевіряючих органів, зростанню сочіально-відповідальних інвестицій.

Ключові слова: малий бізнес, підприємництво, конкурентна перевага, соціальна відповідальність, соціальний розвиток.

\section{СОЦИАЛЬНАЯОТВЕТСТВЕННОСТЬ МАЛОГО БИЗНЕСА КАК ЕГО КОНКУРЕНТНОЕ ПРЕИМУЩЕСТВО}

\author{
Полякова Е.Н., к.э.н., доцент, \\ Хорочиева Е.В., магистр (УкрГУЖТ)
}

В статье исследованы основные проблемы развития малого бизнеса в Украине. Выявлены основные конкурентные преимущества и проанализированы черты моделей соииальной ответственности фирм. Установлено, что низкая степень доходности и короткий жизненньй цикл мальх предприятий, проблемы, связанные с дефииитом кадров, нехваткой производственньхх и офисных помещзений преврашаются в мощнный сдерживающий фактор утверждения института социальной ответственности в малом бизнесе.

Определено, что решение указанных проблем должно стать одним из ключевых направлений государственной политики, поскольку именно малое предпринимательство будет способствовать значительному повымению эффективности реализации

(С Полякова O.M., Хорошаєва Є.В.
Вісник економіки транспорту і промисловості № 60, 2017 